\title{
Spatial distribution and extent of environmental risks of strontium metal concentration in water and bottom sediments of Nile River, Egypt
}

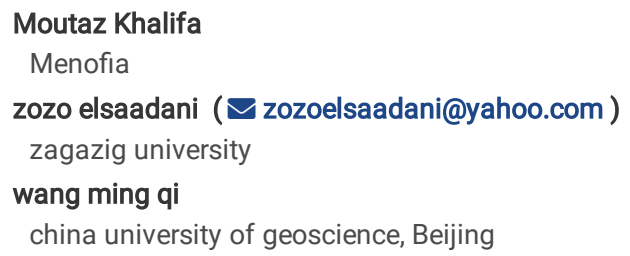

\section{Research Article}

Keywords: Nile River, Contamination, Fractionation, water, Strontium

Posted Date: February 16th, 2022

DOI: https://doi.org/10.21203/rs.3.rs-1337370/v1

License: @ (i) This work is licensed under a Creative Commons Attribution 4.0 International License. Read Full License 


\section{Abstract}

Strontium is one of the rare heavy metals found in the sediments and water of the Nile River. By examining the metal concentration in 69 sampling points along the river between two Nile banks and the Middle, we could throw further light on its dispersion in the current study. High Sr concentrations were found in the eastern>western>middle regions with average concentrations of $344.3,338.39$, and $327.57 \mathrm{ppm}$, respectively, due to the point sources such as industrial activities, sewage wastes, and agricultural discharge. High Sr concentrations were found in the West and East of Cairo (Samalut and Beni Suef) (395, 397, and $392 \mathrm{ppm}$ ). Various pollution indices, such as the Geo-accumulation index, Contamination factor, and Enrichment factor depiction, were used to determine the pollution level caused by this metal, ranging from low to moderate contamination. According to the extraction fractions, the occurrence nature of the element is as follows: Acid soluble > residual >Fe- Mn oxy-hydroxides (reducible)> organic (Oxidizable). The risk assessment code based on the Acid soluble fraction indicates moderate to high risk. Renal failure and baby bone growth problems are common in Egypt, impacting Sr concentration in sediments. The average Sr concentration in water is around $(221.58 \mu \mathrm{g} / \mathrm{l})$, indicating that the water is perfectly safe to drink. The study's findings are useful in determining the extent of Sr metal pollution in the river. If not monitored, Sr concentration will be an issue in Egypt and Ethiopia following dam construction. After the dam is built, this study will serve as a baseline.

\section{Introduction}

Strontium is a lithophile metallic element in group two of the Periodic Table (heavy metal). Natural strontium is not radioactive and exist in four stable isotopic forms: $\mathrm{sr}^{88}(82.6 \%), \mathrm{sr}^{86}(9.9 \%), \mathrm{sr}^{87}(7.0 \%)$ and $\mathrm{sr}^{84}(0.6 \%)$ representing $0.02-0.03 \%$ of the earth's crust with an average $200-300 \mathrm{mg} / \mathrm{kg}$. It exists in igneous and metamorphic rocks, including granites and sedimentary rocks; it mainly enters the water through leaching from limestone as hydrated Sr+2 and can move down into groundwater (Malina, 2004) or by natural weathering of rocks and soils. Strontium is easily mobilized during weathering, especially in oxidizing acid environments. It is incorporated in clay minerals and strongly fixed by organic matter, so it is highly related to unweathered feldspar minerals because the feldspar is the top $\mathrm{Sr}$ carrier. Sr can replace $\mathrm{Ca}$ in both silicates and non-silicate Ca minerals due to the significant similarity of their ionic radii and replace potassium in silicates and Barium in sulfate minerals. Extraction of Strontium from its ore naturally as the minerals celestite $\left(\mathrm{SrSO}_{4}\right)$ and strontianite $\left(\mathrm{SrCO}_{3}\right)$. These minerals are concentrated into strontium carbonate or other chemicals formed by a series of chemical processes used in making glass products and ceramics, pyrotechnics, paint pigments, fluorescent lights, color television tubes, ferrite magnets, zinc refining, medicines, and other products. The radioactive isotope $\mathrm{Sr}^{89}$ is used as cancer therapeutics to alleviate bone pain while $\mathrm{Sr}^{85}$ in medical applications. Air deposition $\left(0.1 \mu \mathrm{g} / \mathrm{m}^{3}\right) \mathrm{from}$ coal-burning and phosphate fertilizers can also contribute smaller amounts (de Beers Canada, 2013; WHO, 2010). (IARC); The International Agency for cancer research) and EPA. has illustrated that radioactive Strontium is carcinogenic to humans because it emits beta radiation and is deposited inside the body. The biological effects of Strontium are related to its chemical similarity to calcium that is taken into bone instead of calcium that grows bones were weakened, especially in infants; Strontium is readily accumulated in opercula of fish (ATSDR, 2004). The inhalation of stable Strontium in smoke from an ignited roadside affects cardiovascular in humans (Federman \& Sachter, 1997). The anthropogenic activities of industrialized human society have led to the increased local concentration of Strontium (ATSDR, 2004). Sr is accumulated in chronic renal failure patients, an association between osteomalacia and increased bone strontium concentration in dialysis patients (D'Haese et al., 1997, 2000). According to (Soliman et al., 2012) increasing renal failure in Egypt) and bone weekend growth of children let us focus on this metal in water and sediments of the main Nile River stream.

This study aims to monitor Sr metal in bottom sediments and the overlying water of the Nile River in Egypt before the operation of the GERD. This research will be repeated after the GERD operation to investigate the potential subsequent environmental changes on the river due to flow reduction and sediment retention at the GERD. Providing the concentration, distribution, and potential sources of Strontium as a critical heavy metal in the sediments and water of the Nile River mainstream, assess the degree of Strontium contamination by using different pollution indices, determine the mode of occurrences and identify the bioavailability of Strontium based on sequential extraction fractions, focus on the west, Middle, and East of this natural stream, related to anthropogenic sources. No specific scientific investigations regarding the fractionation and concentration distribution of Strontium in Nile sediments, Egypt, have been conducted.

\section{Materials And Methods}

\subsection{Study area}

The Nile is the longest river globally, with about $6700 \mathrm{~km}$ in length. The Nile water in Egypt comes from the Ethiopian highlands $>85 \%$, while from the East African Lake Plateau 15\%. The Nile River enters Egypt at its southern boundary with Sudan and runs through a narrow valley (1000 km long) which varies from 2 to $20 \mathrm{~km}$ in width. Subsequently, it is bifurcated at $25 \mathrm{~km}$ (north of Cairo) into the Rosetta and Damietta branches forming a delta with its base on the Mediterranean Seashore.

Sediments supplied to the Nile are derived from the basaltic Ethiopian Highlands, Precambrian basement rocks of the Arabian-Nubian Shield and Saharan Metacraton, and Phanerozoic sedimentary a contribution from aeolian sources, Red Sea Hills of Egypt also contribute to the River Nile drainage basin (Garzanti et al., 2006, 2015; Padoan et al., 2011; Schneiderman, 1995; Stanley and Wingerath, 1996b). About $65 \%$ of the industrial water needs are supplied by Nile while receives $>57 \%$ of its effluents. Besides the natural sources of toxic waste are the drains during the seasonal flash flood. The Nile receives enormous amounts of agricultural wastewater that carry various chemical pollutants related to the widespread use of agrochemicals. Furthermore, a significant quantity of industrial, municipal, and domestic wastes and street contaminants are drained, directly or indirectly, into the Nile.

Heavy metals in Nile River sediments with toxic limit derived from anthropogenic sources as water treatment plants, heavy traffic, mining, paper, pulp, iron and steel, electric power plants, cement, Chlor-alkali, fertilizers, Sugar refining, oil, and detergents factories, and nitrogen fertilizer plants, (El-Kammar et al., 2009; Badr et al., 2013 ; Abdel-Satar et al., 2017; Badawy et al., 2017, 2020 and Hasaballah et al., 2019) along the riverbank. (Häggroth \& Höglund, 1961) found 
that the vegetables have the highest concentration of Sr related to foliar retention of fall-out and aerosol, salt water samples from red sea contain areseamable amounts of Sr. while the human adult femur and vertebra were found to indicate a very small value of Sr in Egypt. (Panahifar et al., 2019) showed that two elements deposited in the areas of active bone turnover such as growth plates and trabecular bone in rats.

\section{Sampling and geochemical analysis:}

About 23 composite samples were collected from Cairo to Aswan using a grab sampler (Ekman type) washed between sites using distilled Water then river water. A subsample was taken using a plastic spoon, placed into clean sealed polyethylene bags, and then stored at a low temperature inside the icebox. Sediments were dried entirely in an oven at 70खC for around $24 \mathrm{~h}$ and preserved for chemical analysis. The sampling sites' coordinates and elevation were recorded using a GPS tracker (Garmin eTrex 10, Lenexa, KS, US). Representative sediment samples were being homogenized for sieve analysis. For trace elements concentration (acid digestion) treatment, $0.25 \mathrm{~g}$ dry sediment was digested using a mixture of $2 \mathrm{~mL} \mathrm{HCl,} 6 \mathrm{~mL} \mathrm{HNO}$, and $2 \mathrm{~mL} \mathrm{HF}$. Then digestion solutions were treated using ICP-AES (Agilent 5110, USA) and ICP-MS (Agilent 7900, USA) respectively at ALS CEMEX (Guangzhou) Co Ltd-China. The standard calibration solutions were prepared from Agilent multielement calibration standard 8500-6944 (Agilent Technologies, USA). A standard solution containing Rh was used as an internal standard to monitor signal drift during counting. Equipment condition monitoring and quality control were performed by measuring a standard solution after every eight samples analysis. All reagents are used of analytical grade chemicals.

According to water samples, about 23 representative water samples in September 2019 under the water surface about (20-40) cm at the same location of sediments. The $\mathrm{pH}$, temperature, and total dissolved solids (TDS) were measured in situ using a HI98129.HI98130 waterproof PH/EC/TDS and Temperature portable meter (HANNA), USA. Before measurement, the meters were calibrated by standard Solutions in addition to Oxidation-reduction potential (ORP) was

also measured in situ using HI98190, a professional waterproof portable PH/ORP Meter, HANNA, USA. All samples were acidified with ultrapure nitric acid in a $30 \mathrm{ml}$ LDPE bottle (prewashed with $10 \%$ nitric acid, ultra-pure Water, and Nile water). The acid used was analytically pure, and the Water was ultra-pure. All water samples were stored at low temperature $(4 \llbracket C)$ until laboratory analysis. Sr contents were determined by inductively coupled plasma mass spectrometry (Table1).

\subsection{Sequential fractionation methods}

Many different sequential extraction techniques have been developed for metal partitioning. Sequential extraction determines trace elements' origin, mobility, and biological and physicochemical availability in solid samples and sediments (du Laing et al., 2007). Single extractions are thus generally used to provide a rapid evaluation of the exchangeable metal fraction in soils and sediments (Rao et al., 2007; Sahuquillo et al., 2003; Salomons, 2006). Several speciation schemes for trace elements in soils or sediments with environmental applications. The most widely used methods are those proposed by (Campanella et al., 1995; Rauret, 1998; Tessier et al., 1979). Chemical fractionation of Sr in sediments was extracted according to the European "Community Bureau of Reference" (BCR) sequential extraction procedure which was proposed (Quevauviller et al., 1997; Ure et al., 1993)(Fig.2). This method has been used widely in determining specific chemical forms of heavy metals in various environmental media, including sediments. This method has been validated using a sediment certified reference material BCR-701 (Rauret \& López-Sánchez, 2006). This method was applied and accepted by many specialists (Davutluoglu et al., 2011; Fernández-Ondoño et al., 2017; Fiedler et al., 1994; Nemati et al., 2011; Pueyo et al., 2008; Usero et al., 1998; Zimmerman \& Weindorf, 2010), although other short steps of extraction (Ramos et al., 1994). Sediments were completely dried in an oven at $40 \otimes C$ for around $48 \mathrm{~h}$ before the BCR procedure. The KS 4000 ic control shaker (IKA, Germany) was used to agitation the sediments at room temperature for $16 \mathrm{~h}$. We used composite samples from three sides. The extraction of fractions from residue in each step was centrifuged at $3000 \mathrm{rpm}$ for $20 \mathrm{~min}$, and the fraction was put in a polyethylene centrifuge tube. The residue was washed with $20 \mathrm{ml}$ deionized water for 15 minutes in the mechanical shaker then centrifuged at $3000 \mathrm{rpm}$ for 20 min. The fraction(supernatant) was decanted, and the residue was subjected to the next step. This separation is operated at super clean and advanced geochemistry laboratory of China university of geoscience.

All supernatants were decanted into polyethylene containers and refrigerated before analysis. Samples were washed between extraction using $10 \mathrm{~mL}$ ultrapure Water. All the glassware and polypropylene ware were soaked overnight in dilute nitric or hydrochloric acid, then rinsed with deionized water before use. The residual part of the samples was digested by a mixture of acid $\left(\mathrm{HNO}_{3}+\mathrm{HF}+\mathrm{HClO}_{4}\right)(\mathrm{Bai}$ et al., 2011). All the reagents and standard solutions used were of guarantee grade. The concentration of metals was determined by Inductively Coupled Plasma Mass Spectrometry (ICP-MS, Agilent 7500, USA). The results were recovered ranging from 94 to $102(n=4)$. The extraction method is summarized in the flow chart scheme in (Fig.2).

\subsection{Environmental pollution indices}

Many techniques have been used to estimate metal pollution in sediments. In this study, pollution levels have been determined using pollution indices as contamination factor, enrichment factor, Index of geo-accumulation, pollution. The selection of background value is the essential parameter to interpret valuable geochemical data, so (Salminen et al., 2005) is chosen to be the background.

\section{A. The geo-accumulation index $\left(\mathrm{I}_{\text {geo }}\right)$ :}

This index is a single metal approach to evaluate the sediment contamination with heavy metals and quantify the intensity of heavy metal contamination in terrestrial, aquatic, and marine environments (Gaur et al., 2005; Moshood N. \& Shinichi, 2009; Ozkan \& Buyukisik, 2012). Geo-accumulation index $\left(\mathbf{I}_{\mathbf{g e o}}\right)$ is considered the metal concentrations related to reference or pre-industrial sediments of the study area. It is calculated using the following relations (Muller, 1969).

1) $I_{\text {geo }}=\log _{2}\left(C_{n} / 1.5 \times B_{n}\right)$ 
Where $\mathrm{C}_{n}$ : is the concentration of metal in the sediments, $\mathrm{B}_{\mathrm{n}}$ : Geochemical background of the element according to (Salminen et al., 2005), and 1.5 is the background matrix correction in factor due to lithogenic effects. I geo values classified as followed: I geo $<0$ no pollution, I geo (0-1) no to moderate pollution, I geo (1-2) moderate pollution, I geo (2-3) moderate to heavy pollution, I geo (3-4) heavy pollution, I geo (4-5) heavy to extreme pollution and I geo > extreme pollution from unpolluted to very extremely polluted (Muller, 1969).

\section{B. The contamination factor (CF):}

It is an indicator to assess the contamination status of sediments in aquatic ecosystems (Abrahim \& Parker, 2008; Rabajczyk et al., 2011) and is used to express the contamination degree with a single metal. The contamination factor calculated according to this equation:

\section{2) $C F=C_{n} / B_{n}$}

$\mathbf{C}_{n}$ is the concentration of metal and $\mathbf{B}_{n}$ is the background. The contamination degrees can be categorized according to their values to: $C F<1$ (low pollution), $1<\mathrm{CF} 3$ (moderate pollution), $3<\mathrm{CF}<6$ (high pollution) and $\mathrm{CF}>6$ (very high pollution), (Hakanson, 1979) .

\section{Enrichment factor, EF.}

It was calculated to determine the anthropogenic origins (contamination) levels of metals in sediments. Geochemical normalization of the heavy metals data to a conservative element, such as Al, Fe, was employed to identify abnormal metal concentrations. Many authors used Al to normalize heavy metal contaminates. In this study also, Al was used as well to differentiate natural from anthropogenic components. The metal EF is calculated as follow (Ergin et al., 1991):

\section{3) $\mathrm{EF}=(\mathrm{M} / \mathrm{Al})_{\text {sample }} /(\mathrm{M} / \mathrm{Al})_{\text {background }}$}

Where $\mathrm{M}$ : is the metal concentration. Ef values are classified to EF $\leq 2$ (low enrichment), EF range from 2 to 5 is moderate enrichment, $\mathrm{EF}$ (5-20) is high enrichment, EF range (20-40) very enrichment and EF>40 is extremely enrichment according to (Diop et al., 2015).

\section{Results And Discussion}

\subsection{Distribution and assessment pollution of Strontium:}

In the present study, the distribution of Strontium in Sixty- Nine sampling locations of about twenty-three positions along the river from West, Middle, and East (Fig. 1) and (Table 1). The average concentration of Sr is (336.75ppm) and ranges from(187-397ppm). The highest value was recorded at the sample of Cairo from the west and the East of Samalut and Beni Suef with values (395, 397, and 392 ppm) respectively. Strontium average at East>West>Middle with values $(344.3,338.39$, and $327.57 \mathrm{ppm})$ respectively, indicating the high potential anthropogenic sources at two sides of Nile, (Fig.3) and (Table 1). The upper continental crust (UCC) value of Sr is (316ppm) according to (Wedepohl, 1995), is lower than the maximum and higher than the minimum of this study value indicating the depletion of $\mathrm{Sr}$ at selected locations and also enrichment at specific sites, while about $450 \mathrm{mg} / \mathrm{kg}$ (Mason \& Moore, 1982). Its average in granite is $285 \mathrm{mg} / \mathrm{kg}$ and in basalt $465 \mathrm{mg} / \mathrm{kg}$ according to (Bowen, 1979) while high concentrations (1000 mg/kg) have been mainly recorded in anorthite (Wedepohl, 1995), a crustal average of (384 mg/kg) (Mielke, 1979). The median strontium concentration was $126 \mathrm{mg} / \mathrm{kg}$ in European stream sediments, while the average in worldwide soil is about $240 \mathrm{mg} / \mathrm{kg}$ (ATSDR, 2004). The lowest value for Strontium recorded by the geochemical atlas of Europe (Finland) is about (171ppm) (Salminen et al., 2005). At River Kortalaiyar, India, Strontium is moderate pollution with concentration (22-512ppm) (Jerin \& Periakaruppan, 2015). According to (El-Sorogy et al., 2018), the Sr enrichment factor is about (98.87), implying anthropogenic sources in Al-Jubail industrial city, at Dammam, Saudi Arabia. The negative correlation between $\mathrm{Sr}$ with some principal oxides as $\left(\mathrm{SiO}_{2}, \mathrm{Al}_{2} \mathrm{O}_{3}, \mathrm{MnO}, \mathrm{K}_{2} \mathrm{O}\right.$, and $\left.\mathrm{P} 2 \mathrm{O} 5\right)(-0.48,-0.08,-0.31,-0.58$, and -0.61$)$ respectively, slightly positive with $\mathrm{CaO})(0.42)$ and no relation with $\left(\mathrm{TiO}_{2}, \mathrm{Fe}_{2} \mathrm{O}_{3}, \mathrm{MgO}, \mathrm{Na}_{2} \mathrm{O}\right.$ and clay\%), (Table) indicated its anthropogenic and geogenic source. High concentration of $\mathrm{CaO}$ oxide and high $\mathrm{Sr}$ concentration at Samalut eastern sample with value (18.96 and 397 ppm) showing the high substitution between them. The upstream from (Kom Umbo to Tahta) about (8602 ppm), Middle stream from (Sohag-Minya) about (7782 ppm) and downstream from (Biba-Cairo) about (6193 ppm). There is an increase from downstream to upstream (North to South) in the strontium concentration, which is contrary to other heavy metals according to (Abou El-Anwar et al., 2018). The enrichment of the metal may lead to pollution. The pollution by the metal is best assessed using various pollution indices as the Geo-accumulation index ( $\left.\mathrm{I}_{\text {geo }}\right)$, Enrichment factor (E.F.), and Contamination factor (CF). The average $\mathrm{I}_{\text {geo }}$ value of Sr in the sampling locations is shown in (Table 1) and Fig. (4), elucidating no to moderate pollution according to (Muller, 1969) (Table 4). All values were calculated less than one, and the highest discount (0.61 and 0.63) at the eastern of (Samalut and BeniSuef). The CF average of Sr is (1.97) with a range from 1.09 to 2.32 (Table 2) and Fig. (4). The CF of East>West>middle. Cairo west and Beni Suef East recorded the highest value of CF (2.29 and 2.32). Since the CF index for Sr is between (1-3) in all sampling locations, the moderate level of contamination is ascertained according to (Hakanson 1979), Table (3). The EF average is (1.89)) with a range from 2.92 to 1.27 illustrating low to moderate enrichment according to (Diop et al., 2015) (Table 4). The Eastern samples of Edfu and Samalut recorded the highest value of EF (2.8 and 2.92) (Table 2) and Fig. (4) due to the proximity of the ferrosilicon industry and the phosphate company, in addition to domestic and agricultural wastes. The EF of East>West>middle. The Strontium pollution may affect bone growth in children. And cause a change in the structure of dental. In adults, Sr may increase the bone density and badly affect renal failure patients. The isotope $\mathrm{Sr}^{90}$ is very carcinogenic, causing bone cancer and leukemia. It is evident from the pollution indices that the Nile River is at the average of pollution by Sr. The present study reveals that the slightly enriched of $\mathrm{Sr}$ concentration in the river. The enrichment if not monitored may progress. A survey in turkey suggested a relationship between strontium exposure and childhood rickets.

\subsection{Sequential extraction:}


Strontium is found in small amounts as well as the largest sources of exposure to Strontium are Food and drinking water. Due to the nature of Strontium, some of it gets into fish, vegetables, and livestock. Leafy vegetables, grain, and dairy products contribute the greatest percentage of dietary Strontium to humans. Strontium acts like calcium in the body when entering the bloodstream and is distributed throughout the body; it enters and leaves cells quite easily. The bioaccumulation availability, reactivity, and mobility are determined by the metal chemical form making the chemical speciation study necessary (Morrison, 1989). The different chemical forms of Strontium can affect the solubility and mobility of the metal from sediments. Metals bound to the exchangeable fraction are available, whereas those included in the carbonate/adsorbed phases become more mobile and easily available with increasing acidity. The residual fraction represents the unreactive phase. The order of strontium fractions is as follow: Acid soluble $>$ residual $>$ Fe- Mn oxy-hydroxides (reducible)> organic (Oxidizable) (Fig.5). The fractions are in ranges as follow (26.22-70.28\%) for Acid soluble (exchangeable and carbonate), (4.59-13.68\%) for Fe-Mn oxyhydroxide, (0.09-0.49\%) for organic and (22.47-64.18\%) for residual fractions (Table 5 ). At (Minya, Tahta, Qena, and Edfu), Strontium was mostly concentrated in the residual fraction $>60 \%$. According to the Risk assessment code (RAC), It represents exchangeable fraction and carbonate percent (Acid soluble). Nile sediments samples are medium to high risk, except Cairo, Helwan, Giza, and Esna are very high risk (Fig.6). This metal species posed a medium-high risk and easily can enter the food chain. By hetero ionic exchange at high strontium concentrations, the element may replace calcium in bone (Mattar, 1979; Querido et al., 2016). Incorporating the greater-sized strontium ions in the bone will affect a mild crystal lattice distortion (Eisenberg E, 1973). Accumulation of $\mathrm{Sr}$ in chronic renal failure patients an association between osteomalacia and increased bone strontium concentrations in dialysis patients (D'Haese et al., 1997, 2000). Water-insoluble strontium compounds may change to soluble forms. Strontium in the ionic form (Sr+2) represents the exchangeable fraction soluble in water (labile in soil) (Heuel-Fabianek, 2014; Lee, 2008). (Häggroth \& Höglund, 1961) found that Sr content amount differentiated between the vegetables, salt water and human adult femur and vertebra in Egypt.

\subsection{Multivariate statistical analysis (Cluster analysis)}

There is a need to identify the sources of heavy metal pollution in ecosystems while evaluating the contribution of natural and anthropogenic factors posed by individual elements. It is considered an effective tool for providing suggestive information about heavy metal sources and pathways (Hou et al., 2013). Cluster analysis was conducted by considering Strontium concentration at sediments and water with Risk assessment code (RAC) are the variables along Nile River mainstream to evaluate the anthropogenic sources (Fig.7). The cluster analysis indicates three sources for stations (Fig.7) as follow: the Cluster 2 contains tree sampling site (Cairo, Helwan, and Giza.) mainly located near to industrial activities as Iron and steel factory, and sugar refining plant), cluster 1 consist of one sampling site (Aswan ) near to domestic source, and cluster3 consist of 18 sampling sites (Beni Mazar, Esna, Naser, Sidfa, Luxor, Assyut, AbuTij, Biba, KomUmbo, Qena, Minya, Nagaa Hammadi, Tahta, Armant, Edfu, Girga, Samalut, and Sohag) the most of them located near to the complex of urbanized area, water treatment plant, sugar refining, and agricultural discharge.

\subsection{In Water}

According to (Badr et al., 2013), agricultural, industrial, and domestic activities discharged vast quantities of waste in rivers worldwide because of population growth and industrialization. Strontium in water finds as a hydrated ion and can react with elements like nitrogen (N2), fluorine (F2), and sulfur (S) (Skoryna, 1981). Aqueous Strontium can be sorbed to the surface of certain minerals. Strontium average of water in this study is $221.58 \mu \mathrm{g} / \mathrm{L}$. At the same time, the upstream from (Kom Umbo toTahta) is about $(1891.5 \mu \mathrm{g} / \mathrm{L})$, the Middle stream from (Tahta-Minya) is about (1741.1 $\mu \mathrm{g} / \mathrm{L})$ and downstream from (Biba-Cairo) is about $(1463.7 \mu \mathrm{g} / \mathrm{L})$. There is a slight increase from downstream to upstream in the Strontium concentration following sediment concentration. Sr in seawater is about eight $\mathrm{mg} / \mathrm{L}$ (ATSDR, 2004). Based on the Canada health review (2018), the proposed guideline for Strontium in drinking water is a maximum acceptable concentration (MAC.) of $7.0 \mathrm{mg} / \mathrm{L}$. Dissolved Sr loads in the world's river waters have been reported by (Gaillardet et al., 2003) ranged from few $\mathrm{ng} / \mathrm{L}$ to nearly $(100 \mu \mathrm{g} / \mathrm{L})$ with an average $(60 \mu \mathrm{g} / \mathrm{L})$. According to (Salminen et al., 2005) of Finland atlas, the strontium concentration in water is about $0.327 \mathrm{mg} / \mathrm{L}$. The quality water parameters were measured using advanced tools like (P.H., Oxidation-reduction potential (ORP), Temperature, and Total dissolved solids (TDS.)). O.R.P. ranged from 239 to 441 with an average (345.87) at studied samples less than (WHO, 2011) limit value (700 MV). The Temperature ranged from 26区 to 31.3区 with an average (28.08区). P.H. ranged from 7.9 to 9 with an average (8.4); however, P.H. according to (WHO, 2011),(EPA, 2018) and Egyptian regulation (6.5-8), (6.5-8.5) and (7-8.5), respectively. The highest P.H. (9) was recorded at Qena. T.D.S. ranges from (146 -188) with an average (158.39) less than values limits of Egyptian regulation and (EPA, 2018) (500 mg/g) (Table 5). Strontium is positively correlated with (TDS, ORP and Temp) $(0.75,0.22$, and 0.41$)$ respectively and negatively with $\mathrm{PH}(-0.54)$ (Table 6). EPA recommends that stable strontium levels in drinking water should not be more than $(4 \mathrm{mg} / \mathrm{L})$. Most forms of radioactive and stable Strontium are dissolved in water. Stable Strontium dissolved in water comes from Strontium in rocks and soil that water runs over, so it may be move deeper into the ground and enter the groundwater. Strontium dust from the air represents a small part of the Strontium found in water. Some strontium is suspended in water. The strontium concentration in water is less than EPA value(EPA, 2012; US EPA, 2013); $4 \mathrm{mg} / \mathrm{l}$ and $1.5 \mathrm{mg} / \mathrm{l})$, so it is safe, but it will be severe if not monitored because many kids in Egypt suffer from bone weakness.

\section{Conclusion}

The present study focusses on Sr in Nile River sediment and water indicating that the concentration of Sr isn't very significant. It warns us of the condition shortly, so we need a common way towards monitoring the enrichment of Strontium. The pollution indices illustrate low to moderate pollution degree while Cluster analysis depicts three anthropogenic sources of Sr. Strontium fractions: Acid soluble > residual >Fe- Mn oxy-hydroxides (reducible) > organic (Oxidizable). The risk assessment of Sr from moderate to high according to the exchangeable fraction percent except Cairo, Helwan, Giza, and Esna are very high risk. The Sr water concentration is safe. Near to the agricultural effluents and industrial point source, the pollution must be checked in a determinized manner, especially before and after the Ethiopian dam operation. Must continue Monitoring pollution because of Sr's lousy effect on renal failure patients and the bone strength of infants to solve the two problems faced in Egypt.

\section{Declarations}


Please add the following to the declarations: The authors declare no conflict interest

\section{References}

Abdel-Satar, A. M., Ali, M. H., \& Goher, M. E. (2017). Indices of water quality and metal pollution of Nile River, Egypt. The Egyptian Journal of Aquatic Research, 43(1), 21-29. https://doi.org/10.1016/J.EJAR.2016.12.006

Abou El-Anwar, E. A. , Samy, Y. M. , \& Salman, S. A. ,. (2018). Heavy metals hazard in Rosetta Branch sediments, Egypt,. J. Mater. Environ. Sci. 9 (7). . https://www.researchgate.net/publication/326468677_Heavy_metals_hazard_in_Rosetta_Branch_sediments_Egypt

Abrahim, G. M. S., \& Parker, R. J. (2008). Assessment of heavy metal enrichment factors and the degree of contamination in marine sediments from Tamaki Estuary, Auckland, New Zealand. Environmental Monitoring and Assessment, 136(1-3), 227-238. https://doi.org/10.1007/S10661-007-9678-2

ATSDR. (2004). Agency for Toxic Substances and Disease Registry. https://www.atsdr.cdc.gov/

Badawy, W. M., Duliu, O. G., Frontasyeva, M. v., El-Samman, H., \& Mamikhin, S. v. (2020). Dataset of elemental compositions and pollution indices of soil and sediments: Nile River and delta -Egypt. Data in Brief, 28, 105009. https://doi.org/10.1016/J.DIB.2019.105009

Badawy, W. M., Ghanim, E. H., Duliu, O. G., el Samman, H., \& Frontasyeva, M. v. (2017). Major and trace element distribution in soil and sediments from the Egyptian central Nile Valley. Journal of African Earth Sciences, 131, 53-61. https://doi.org/10.1016/J.JAFREARSCI.2017.03.029

Badr, E.-S., El-Sonbati, M., \& Nassef, H. (2013). Water Quality Assessment in the Nile River, Damietta Branch, Egypt. Catrina: The International Journal of Environmental Sciences, 8(1), 41-50. https://doi.org/10.12816/0010762

Bai, J., Cui, B., Chen, B., Zhang, K., Deng, W., Gao, H., \& Xiao, R. (2011). Spatial distribution and ecological risk assessment of heavy metals in surface sediments from a typical plateau lake wetland, China. Ecological Modelling, 222(2), 301-306. https://doi.org/10.1016/J.ECOLMODEL.2009.12.002

Bowen, H. J. M. (1979). Environmental Chemistry of the Elements. . Academic Press, New York.

Campanella, L., D’Orazio, D., Petronio, B. M., \& Pietrantonio, E. (1995). Proposal for a metal speciation study in sediments. Analytica Chimica Acta, 309(1-3), 387-393. https://doi.org/10.1016/0003-2670(95)00025-U

Davutluoglu, O. I., Seckin, G., Ersu, C. B., Yilmaz, T., \& Sari, B. (2011). Heavy metal content and distribution in surface sediments of the Seyhan River, Turkey. Journal of Environmental Management, 92(9), 2250-2259. https://doi.org/10.1016/J.JENVMAN.2011.04.013

de Beers Canada. (2013). Snap Lake Mine: Strontium response plan. Report No. MV2011L2-0004. File: L020. .

D’Haese, P. C., Schrooten, I., Goodman, W. G., Cabrera, W. E., Lamberts, L. v., Elseviers, M. M., Couttenye, M. M., \& de Broe, M. E. (2000). Increased bone strontium levels in hemodialysis patients with osteomalacia. Kidney International, 57(3), 1107-1114. https://doi.org/10.1046/J.1523-1755.2000.00938.X

D’Haese, P. C., van Landeghem, G. F., Lamberts, L. v., Bekaert, V. A., Schrooten, I., \& de Broe, M. E. (1997). Measurement of strontium in serum, urine, bone, and soft tissues by Zeeman atomic absorption spectrometry. Clinical Chemistry, 43(1), 121-128. https://doi.org/10.1093/CLINCHEM/43.1.121

Diop, C., Dewaelé, D., Cazier, F., Diouf, A., \& Ouddane, B. (2015). Assessment of trace metals contamination level, bioavailability and toxicity in sediments from Dakar coast and Saint Louis estuary in Senegal, West Africa. Chemosphere, 138, 980-987. https://doi.org/10.1016/J.CHEMOSPHERE.2014.12.041

du Laing, G., Vandecasteele, B., de Grauwe, P., Moors, W., Lesage, E., Meers, E., Tack, F. M. G., \& Verloo, M. G. (2007). Factors affecting metal concentrations in the upper sediment layer of intertidal reedbeds along the river Scheldt. Journal of Environmental Monitoring, 9(5), 449-455.

https://doi.org/10.1039/B618772B

Eisenberg E. (1973). The biological metabolism of strontium. In: Zipkin I (ed.) Biological Mineralization. . John Wiley \& Sons, New York, NY, U.S.A., 435-442.

El-Kammar, A., Ali, B. H., \& El-Badry, A. (2009). Environmental Geochemistry of River Nile Bottom Sediments Between Aswan and Isna, Upper Egypt. Undefined.

El-Sorogy, A., Al-Kahtany, K., Youssef, M., Al-Kahtany, F., \& Al-Malky, M. (2018). Distribution and metal contamination in the coastal sediments of Dammam AlJubail area, Arabian Gulf, Saudi Arabia. Marine Pollution Bulletin, 128, 8-16. https://doi.org/10.1016/J.MARPOLBUL.2017.12.066

EPA. (2012). pH in Water: Monitoring and Assessment, Water Quality Condition. The United States Environmental Protection Agency, 5:4.

EPA. (2018). Edition of the Drinking Water Standards and Health Advisories. Office of Water U.S. Environmental Protection Agency Washington, D.C.

Ergin, M., Saydam, C., Baştürk, Ö., Erdem, E., \& Yörük, R. (1991). Heavy metal concentrations in surface sediments from the two coastal inlets (Golden Horn Estuary and İzmit Bay) of the northeastern Sea of Marmara. Chemical Geology, 91(3), 269-285. https://doi.org/10.1016/0009-2541(91)90004-B

Federman, J. H., \& Sachter, J. J. (1997). Status asthmaticus in a paramedic following exposure to a roadside flare: a case report. The Journal of Emergency Medicine, 15(1), 87-89. https://doi.org/10.1016/S0736-4679(96)00245-4 
Fernández-Ondoño, E., Bacchetta, G., Lallena, A. M., Navarro, F. B., Ortiz, I., \& Jiménez, M. N. (2017). Use of BCR sequential extraction procedures for soils and plant metal transfer predictions in contaminated mine tailings in Sardinia. Journal of Geochemical Exploration, 172, $133-141$.

https://doi.org/10.1016/J.GEXPL0.2016.09.013

Fiedler, H. D., López-Sánchez, J. F., Rubio, R., Rauret, G., Quevauviller, P., Ure, A. M., \& Muntau, H. (1994). Study of the stability of extractable trace metal contents in a river sediment using sequential extraction. Analyst, 119(6), 1109-1114. https://doi.org/10.1039/AN9941901109

Gaillardet, J., Viers, J., \& Dupré, B. (2003). Trace Elements in River Waters. TrGeo, 5, 605. https://doi.org/10.1016/B0-08-043751-6/05165-3

Garzanti, E., Andò, S., Padoan, M., Vezzoli, G., \& el Kammar, A. (2015). The modern Nile sediment system: Processes and products. Quaternary Science Reviews, 130, 9-56. https://doi.org/10.1016/J.QUASCIREV.2015.07.011

Garzanti, E., Andò, S., Vezzoli, G., Ali Abdel Megid, A., \& el Kammar, A. (2006). Petrology of Nile River sands (Ethiopia and Sudan): Sediment budgets and erosion patterns. Earth and Planetary Science Letters, 252(3-4), 327-341. https://doi.org/10.1016/J.EPSL.2006.10.001

Gaur, V. K., Gupta, S. K., Pandey, S. D., Gopal, K., \& Misra, V. (2005). Distribution of heavy metals in sediment and water of river Gomti. Environmental Monitoring and Assessment 2005 102:1, 102(1), 419-433. https://doi.org/10.1007/S10661-005-6395-6

Häggroth, S., \& Höglund, G. (1961). STRONTIUM 90, STABLE STRONTIUM AND STABLE CALCIUM IN SOIL, FOOD ITEMS, WATER AND HUMAN BONE IN EGYPT (U.A.R.). Experimental Cell Research, 24(1), 80-87. https://doi.org/10.1016/0014-4827(61)90249-X

Hakanson, L. (1979). Stress testing and the new technetium-99m cardiac imaging agents. . Am. J. Card. Imaging, 5, 32-36.

Hasaballah, A. F., Hegazy, T. A., Ibrahim, M. S., \& El-Emam, D. A. (2019). Assessment of water and sediment quality of the river nile, damietta branch, Egypt. Egyptian Journal of Aquatic Biology and Fisheries, 23(5 Special Issue), 55-65. https://doi.org/10.21608/EJABF.2019.64835

Heuel-Fabianek, B. (2014). Partition Coefficients (Kd) for the Modelling of Transport Processes of Radionuclides in Groundwater.Division of Safety and Radiation Protection, Berichte des Forschungszentrums Jülich (ed.). Helmholtz Association of German Research Centres, 51 pp. Available at: www.researchgate.net/publication/303250933_Partition_Coefficients_Kd_for_the_Modelling_of_Transport_Processes_of_Radionuclides_in_Groundwater. https://www.researchgate.net/publication/303250933_Partition_Coefficients_Kd_for_the_Modelling_of_Transport_Processes_of_Radionuclides_in_Groundwat $\epsilon$

Hou, D., He, J., Lü, C., Ren, L., Fan, Q., Wang, J., \& Xie, Z. (2013). Distribution characteristics and potential ecological risk assessment of heavy metals (Cu, Pb, $\mathrm{Zn}, \mathrm{Cd}$ ) in water and sediments from Lake Dalinouer, China. Ecotoxicology and Environmental Safety, 93, 135-144.

https://doi.org/10.1016/J.ECOENV.2013.03.012

Jerin, B., \& Periakaruppan, P. (2015). Distribution of strontium in the sediments of river Kortalaiyar, Tamilnadu, India. Int. J. Chem. Sci.: 13(4).

https://www.researchgate.net/publication/298083246_Distribution_of_strontium_in_the_sediments_of_river_Kortalaiyar_Tamilnadu_India

Lee, S. S. (2008). The effect of dissolved organic matter on distribution of heavy metals at the mica-water interface. . ProQuest, Chicago, Illinois. , 111.

Malina, G. (2004). Ecotoxicological and environmental problems associated with the former chemical plant in Tarnowskie Gory, Poland. Toxicology, 205(3), 157-172. https://doi.org/10.1016/J.TOX.2004.06.064

Mason, B., \& Moore, CB. (1982). Principles of Geochemistry. . JohnWiley \& Sons, New York, NY, U.S.A.

Mattar AG, S. B. (1979). Bone tracers: Radionuclide imaging and related techniques. In: Simmons DJ, Kusrin AS (eds.) . Skeletal Research: An Experimental Approach. Academic Press, New York, NY, U.S.A., 455-486.

Mielke, J. E. (1979). Composition of the Earth's Crust and Distribution of the Elements. In: Siegel, F.R. (Ed.), Review of Research on Modern Problems in Geochemistry, UNESCO Report, Paris, 13-37.

Morrison, G. M. P. .. (1989). Trace element speciation and its relation to bioavailability and toxicity in natural water. CRC Press, Boca Raton, FL, $25-41$.

Moshood N., T., \& Shinichi, O. (2009). Hydrogeochemical Assessment of Metals Contamination in an Urban Drainage System: A Case Study of Osogbo Township, SW-Nigeria. Journal of Water Resource and Protection, 2009(03), 164-173. https://doi.org/10.4236/JWARP.2009.13021

Muller, G. M. M. G. M. G. M. G. P. (1969). Index of geo-accumulation in sediments of the Rhine River. J. Geol., 2, 108-118.

Nemati, K., Bakar, N. K. A., Abas, M. R., \& Sobhanzadeh, E. (2011). Speciation of heavy metals by modified BCR sequential extraction procedure in different depths of sediments from Sungai Buloh, Selangor, Malaysia. Journal of Hazardous Materials, 192(1), 402-410.

https://doi.org/10.1016/J.JHAZMAT.2011.05.039

Ozkan, E. Y., \& Buyukisik, B. (2012). Geochemical and statistical approach for assessing heavy metal accumulation in the Southern Black Sea sediments. Ekoloji, 83, 11-24. https://doi.org/10.5053/EKOLOJI.2012.832

Padoan, M., Garzanti, E., Harlavan, Y., \& Villa, I. M. (2011). Tracing Nile sediment sources by Sr and Nd isotope signatures (Uganda, Ethiopia, Sudan). Geochimica et Cosmochimica Acta, 75(12), 3627-3644. https://doi.org/10.1016/J.GCA.2011.03.042

Page $7 / 11$ 
Panahifar, A., Chapman, L. D., Weber, L., Samadi, N., \& Cooper, D. M. L. (2019). Biodistribution of strontium and barium in the developing and mature skeleton of rats. Journal of Bone and Mineral Metabolism, 37(3), 385-398. https://doi.org/10.1007/S00774-018-0936-X

Pueyo, M., Mateu, J., Rigol, A., Vidal, M., López-Sánchez, J. F., \& Rauret, G. (2008). Use of the modified BCR three-step sequential extraction procedure for the study of trace element dynamics in contaminated soils. Environmental Pollution, 152(2), 330-341. https://doi.org/10.1016/J.ENVPOL.2007.06.020

Querido, W., Rossi, A. L., \& Farina, M. (2016). The effects of strontium on bone mineral: A review on current knowledge and microanalytical approaches. Micron (Oxford, England: 1993), 80, 122-134. https://doi.org/10.1016/J.MICRON.2015.10.006

Quevauviller, P., Rauret, G., López-Sánchez, J. F., Rubio, R., Ure, A., \& Muntau, H. (1997). Certification of trace metal extractable contents in a sediment reference material (CRM 601) following a three-step sequential extraction procedure. Science of The Total Environment, 205(2-3), 223-234.

https://doi.org/10.1016/S0048-9697(97)00205-2

Rabajczyk, A., Jozwiak, M. A., Jozwiak, M., \& Kozlowski, R. (2011). Heavy metals (Cd, Pb, Cu, Zn, Cr) in bottom sediments and the recultivation of Kielce Lake. Polish Journal of Environmental Studies, 20(4).

Ramos, L., Hernandez, L. M., \& Gonzalez, M. J. (1994). Sequential Fractionation of Copper, Lead, Cadmium and Zinc in Soils from or near Doñana National Park. Journal of Environmental Quality, 23(1), 50-57. https://doi.org/10.2134/JEQ1994.00472425002300010009X

Rao, C. R. M., Sahuquillo, A., \& Lopez Sanchez, J. F. (2007). A Review of the Different Methods Applied in Environmental Geochemistry For Single and Sequential Extraction of Trace Elements in Soils and Related Materials. Water, Air, and Soil Pollution 2007 189:1, 189(1), $291-333$.

https://doi.org/10.1007/S11270-007-9564-0

Rauret, G. (1998). Extraction procedures for the determination of heavy metals in contaminated soil and sediment. Talanta, 46(3), 449-455. https://doi.org/10.1016/S0039-9140(97)00406-2

Rauret, G., \& López-Sánchez, J. F. (2006). New Sediment and Soil CRMs for Extractable Trace Metal Content. Http://Dx.Doi.Org/10.1080/03067310108034155, 79(1), 81-95. https://doi.org/10.1080/03067310108034155

Sahuquillo, A., Rigol, A., \& Rauret, G. (2003). Overview of the use of leaching/extraction tests for risk assessment of trace metals in contaminated soils and sediments. TrAC Trends in Analytical Chemistry, 22(3), 152-159. https://doi.org/10.1016/S0165-9936(03)00303-0

Salminen, R., Batista, M. J., Bidovec, M., Demetriades, A., de Vivo, B., de Vos, W., Gilucis, A., Gregorauskiene, V., Halamic, J., Heitzmann, P., Lima, A., Jordan, G., Klaver, G., Klein, P., Lis, J., Locutura, J., Marsina, K., Maxrecu, A., O’Conor, P. J., ... Tarvainen, T. (2005). Geochemical Atlas of Europe. Part. 1. A Contribution to IUGS/IAGC Global Geochemical Baselines, EuropeanGeoSurveys. GTK. Foregs.

Salomons, W. (2006). Adoption of Common Schemes for Single and Sequential Extractions of Trace Metal in Soils and Sediments. Https://Doi.Org/10.1080/03067319308027607, 51(1-4), 3-4. https://doi.org/10.1080/03067319308027607

Schneiderman, J. S. (1995). Detrital opaque oxides as provenance indicators in River Nile sediments. Journal of Sedimentary Research, 65(4a), 668-674. https://doi.org/10.1306/D4268194-2B26-11D7-8648000102C1865D

Skoryna, SC. (1981). Handbook of stable strontium. . New York, NY: Plenum Press.

Soliman, A. R., Fathy, A., \& Roshd, D. (2012). The growing burden of end-stage renal disease in Egypt. Renal Failure, 34(4), 425-428.

https://doi.org/10.3109/0886022X.2011.649671

Stanley, D. J., \& Wingerath, J. G. (1996). Nile sediment dispersal altered by the Aswan High Dam: The kaolinite trace. Marine Geology, 133(1-2), 1-9. https://doi.org/10.1016/0025-3227(96)00019-9

Tessier, A., Campbell, P. G. C., \& Bisson, M. (1979). Sequential Extraction Procedure for the Speciation of Particulate Trace Metals. Analytical Chemistry, 51(7), 844-851. https://doi.org/10.1021/AC50043A017

Ure, A., Muntau, ph., Quevauviller, P., \& Griepink, B. (1993). Speciation of heavy metals in soils and sediments an account of the improvement and harmonization of extraction techniques undertaken under the auspices of the bcr of the commission of the european communities. International Journal of Environmental Analytical Chemistry, 51(1-4), 135-151. https://doi.org/10.1080/03067319308027619

US EPA. (2014, September 17). "Basic Information about Barium in Drinking Water.

Usero, J., Gamero, M., Morillo, J., \& Gracia, I. (1998). Comparative study of three sequential extraction procedures for metals in marine sediments. Environment International, 24(4), 487-496. https://doi.org/10.1016/S0160-4120(98)00028-2

Wedepohl, K. H. (1995). The Composition of the Continental Crust. Geochim. Cosmochim. Acta, 7(59), 1217-1232.

WHO. (2010). STRONTIUM AND STRONTIUM COMPOUNDS, Concise international chemical assessment document 77. International Programme on Chemical Safety, World Health Organization. 
WHO. (2011). World Health Organization. Guidelines for drinking-water quality - 4th ed.

Zimmerman, A. J., \& Weindorf, D. C. (2010). Heavy Metal and Trace Metal Analysis in Soil by Sequential Extraction: A Review of Procedures. International Journal of Analytical Chemistry, 2010,1-7. https://doi.org/10.1155/2010/387803

\section{Tables}

Tables 1, 2, 4, and 5 are available in the supplementary files section.

Tables 3 and 6 are not available with this version.

\section{Figures}

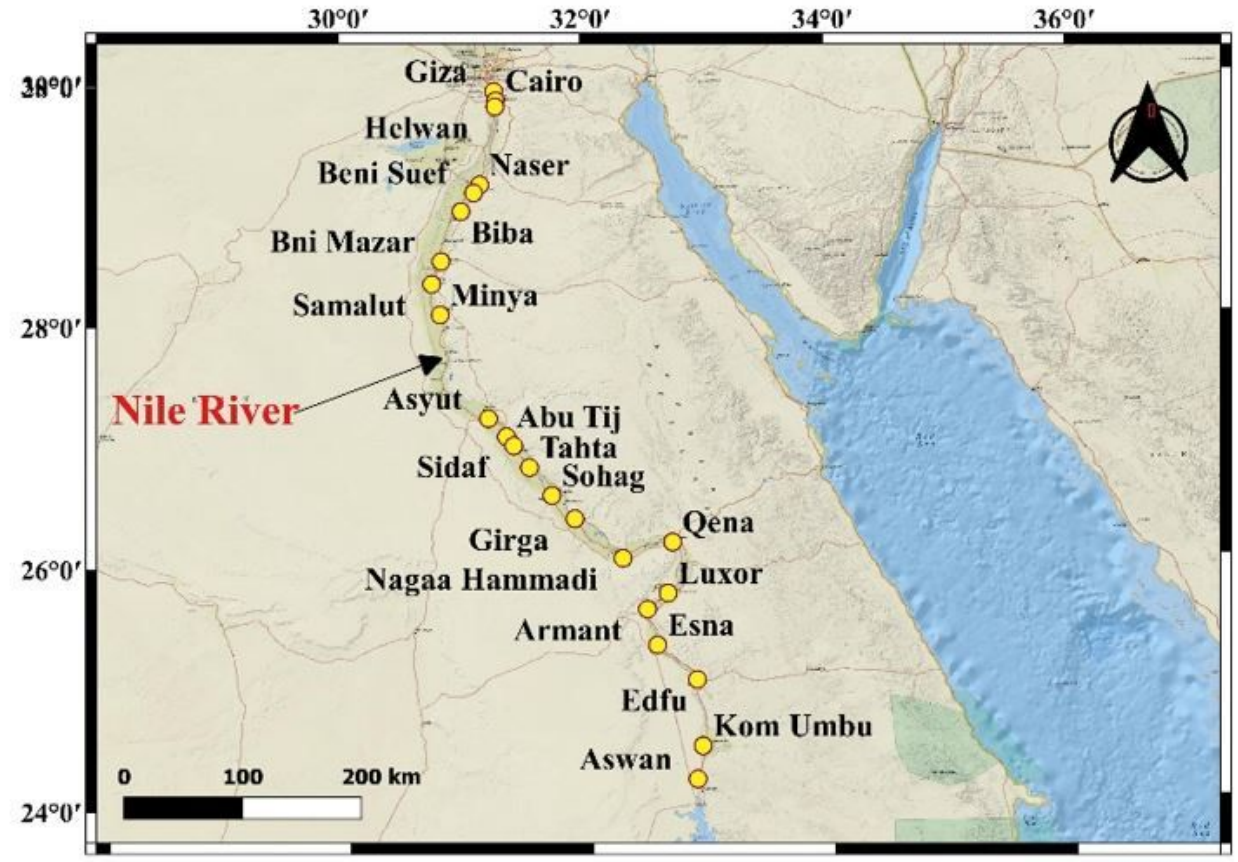

Figure 1

Location map of sampling stations along main river stream. 


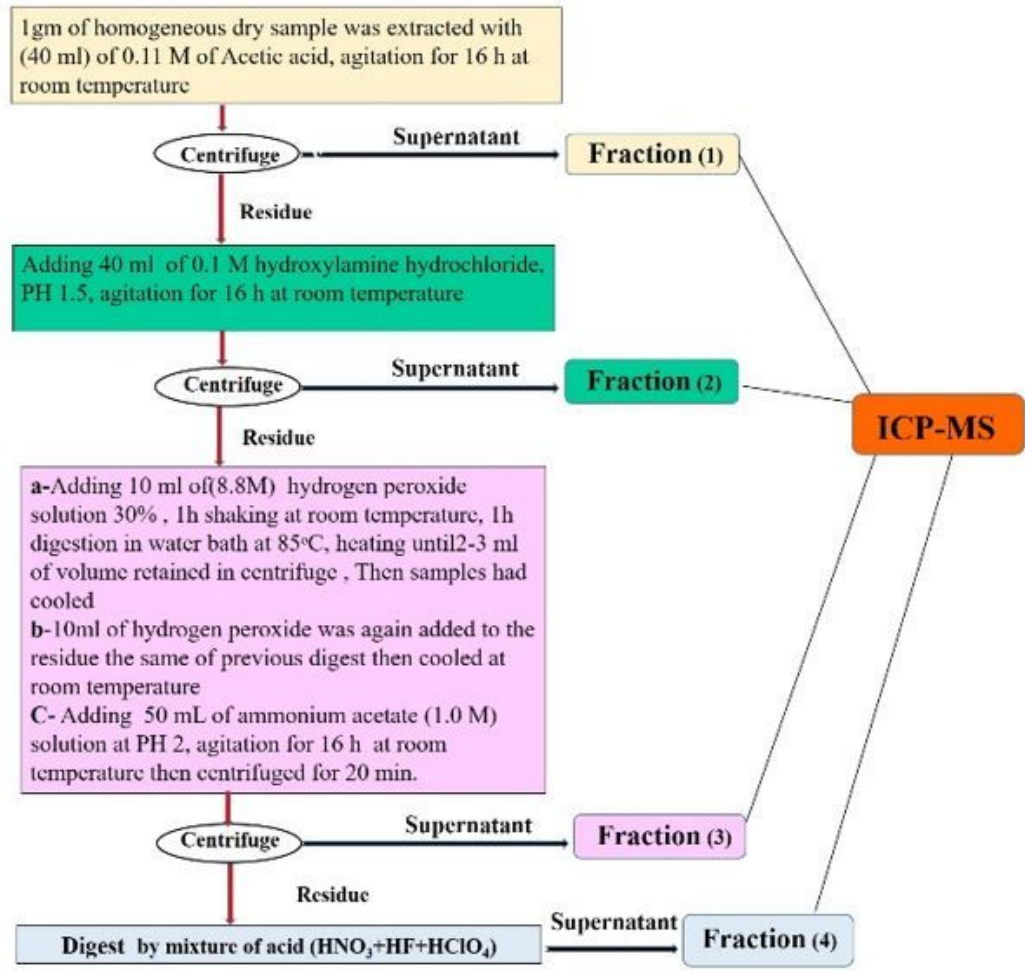

Figure 2

Flowchart of sequential extraction procedures.

Figure 3

Crossed map of strontium concentration ( $\mathrm{ppm}$ ) of the Nile river main stream sediments from West, Middle and East.

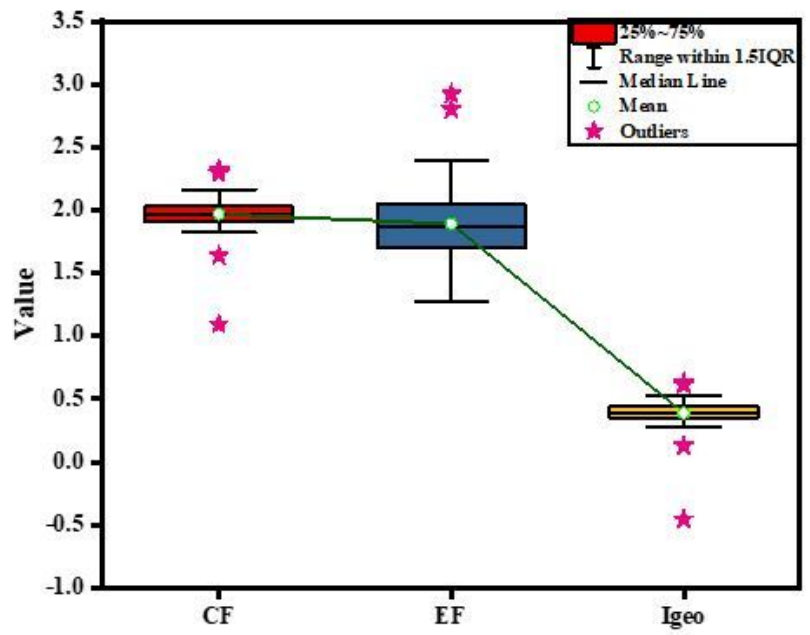

\section{Figure 4}

Box plot of Contamination factor (CF), geo-accumulation index (Igeo)and enrichment factor (EF) of Nile River sediments. 


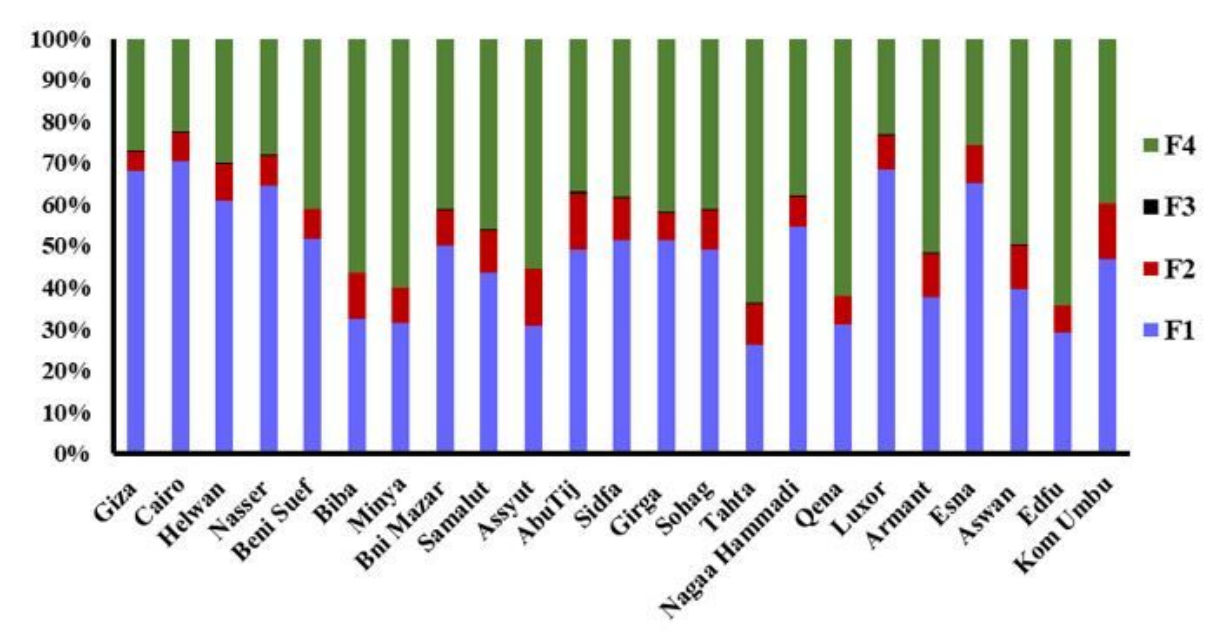

Figure 5

Fractions distribution of Sr in the Nile sediments. F1: Acid soluble; F2: Reducible; F3: Oxidizable fraction; F4: Residual fraction.

Figure 6

Risk assessment code (RAC) at samples location along Nile River main stream.

Figure 7

Dendrogram showing cluster of variables on the basis of similarity of strontium.

\section{Supplementary Files}

This is a list of supplementary files associated with this preprint. Click to download.

- supplementaryforSr.docx

- Tables.docx 